\title{
シリコンフォトニック結晶共振器による放射遷移増強
}

\author{
角倉 久史 ${ }^{1,2}$, 納富 雅也 ${ }^{1,2}$ \\ ${ }^{1}$ 日本電信電話 (株) NTTナノフォトニクスセンタ（†243-0198 神奈川県厚木市森の里若宮3-1） \\ ${ }^{2}$ 日本電信電話 (株) NTT物性科学基礎研究所 (广243-0198 神奈川県厚木市森の里若宮3-1)
}

\section{Enhancement of Radiative Transitions by Silicon Photonic Crystal Cavities}

\author{
Hisashi SUMIKURA ${ }^{1,2}$ and Masaya NOTOMI ${ }^{1,2}$ \\ ${ }^{1}$ NTT Nanophotonics Center, NTT Corp., 3-1 Morinosato Wakamiya, Atsugi, Kanagawa 243-0198 \\ ${ }^{2}$ NTT Basic Research Laboratories, NTT Corp., 3-1 Morinosato Wakamiya, Atsugi, Kanagawa 243-0198
}

(Received November 5, 2013)

\begin{abstract}
Enhancing radiative transitions including spontaneous emission and scattering of silicon ( $\mathrm{Si}$ ) has been of interest for realizing light emitting and quantum optical devices. Here, we demonstrate enhancement of Si spontaneous emission using ultrasmall and high- $Q$ Si photonic crystal $(\mathrm{PhC})$ cavities via the Purcell effect because the emission of bulk $\mathrm{Si}$ is quite weak due to its indirect energy band structure. The photoluminescence of electron-hole droplets in $\mathrm{Si} \mathrm{PhC} \mathrm{cavities} \mathrm{is} \mathrm{resonantly} \mathrm{increased} \mathrm{by} \mathrm{a} \mathrm{factor} \mathrm{of}$ 140. In addition, we observe enhancement of spontaneous Raman scattering of carbon nanotubes by $\mathrm{Si}$ $\mathrm{PhC}$ cavities. These approaches for cavity-enhanced radiative transitions show another useful way for realizing Si-based optical devices.
\end{abstract}

Key Words: Silicon, Photonic crystal, Purcell effect

\section{1. はじめに}

シリコン $(\mathrm{Si})$ 発光デバイスや近年提案されている $\mathrm{Si}$ 中

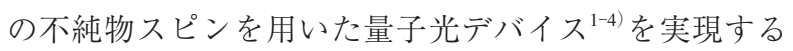
ためには, $\mathrm{Si}$ た発光増強が必要不可欠である。なぜな ら， $\mathrm{Si}$ の発光量子効率は一般的な発光デバイスに用いら れているIII-V族半導体と比べて極めて低いためであ る。これは, Siが間接遷移半導体であるため励起された 電子と正孔の放射再結合 (自然放出) レートが低く, 一方 でオージェ過程などによる非発光再結合レートがより大 きいことに起因している。このような低効率のSi発光を 改善するために, 自然放出レートの増大を目指した研究 が進められている。この自然放出レートは, 放射電磁場 と電子系がとりうる状態密度と電子系の波動関数に依存 する電気双極子遷移モーメントの関数である ${ }^{5)}$. $\mathrm{Si}$ では 運動量保存則に従い自然放出の際にフォノンの放出を伴 うこともあるため, フォノンの状態密度の関数にもな る.

この自然放出レートを大きくする方法は，2つに大別 される，一つは電子のバンド構造を変化させることで直 接遷移化し電気双極子遷移モーメントを大きくする方法 で, 例えばSi結晶に大きな歪を印加してバンド構造を変 形させる6). 特に通信波長帯で発光するゲルマニウムで 精力的に研究が行われており, 歪印加によるフォトルミ ネッセンス (Photoluminescence: PL) 強度の増加が観測さ
れている7)。その他にはサイズ量子化により電子系のエ ネルギーを離散化し，かつ運動量保存則による遷移制限 の緩和する方法がある.Si广ノ粒子や薄膜の作製によっ て, 主に近赤外域における強い発光が報告されてい $3^{8-10)}$.

もう一つの方法は, 放射電磁場の状態密度の増加させ る方法である。これは電子の実準位間の放射遷移を意味 する自然放出だけでなく，仮想準位間の放射遷移である 自然ラマン散乱も増強させることが可能である. そのた め, 先に述べた材料科学による方法とは違ったアプロー チによるSi発光デバイスやラマン光源への応用が期待で きる，そこで本稿では，微小なSi光ナノ共振器における 放射電磁場の大きな状態密度と, それによる自然放出お よび自然ラマン散乱を含む放射遷移の増強について解説 する。

\section{2. 光共振器中の自然放出レート}

近年, 半導体微細加工技術の進歩によってフォトニッ クナノ構造を用いた光の波長もしくはそれ以下の微小領 域で電磁場 (光)の状態密度や電磁場強度分布の制御が可 能となった。ここでは微小な光ナノ共振器による自然放 出レートの増大効果について述べ, いくつかの研究例も 紹介する.

先に述べたとおり自然放出レートは放射電磁場の状態 
(a)

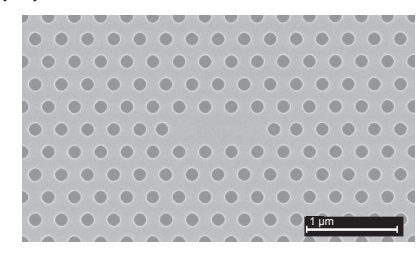

(b)

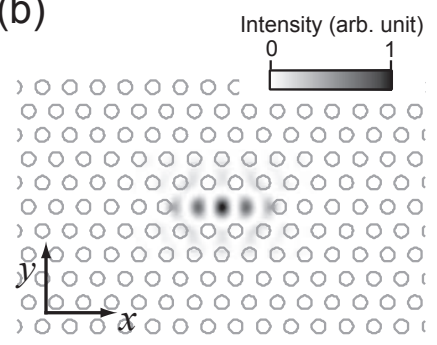

(c)

(d)
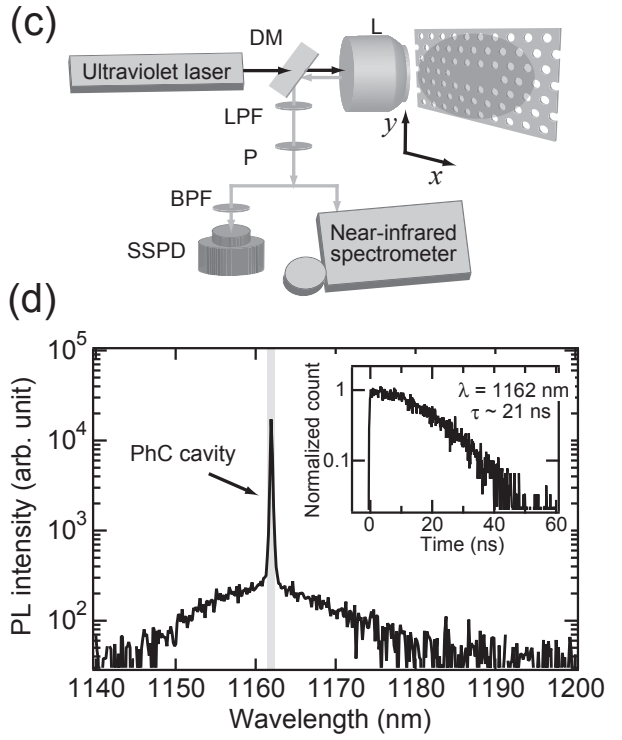

Fig. 1 (a) SEM picture of a Si photonic crystal cavity. The scale bar is $1-\mu \mathrm{m}$ long. (b) Calculated electric field intensity of the y-polarized fundamental cavity mode. (c) Setup for microscopic photoluminescence measurements. DM: dichroic mirror, L: objective, LPF: optical low-pass filter, P: polarizer, BPF: optical band-pass filter, SSPD: superconducting single photon detector. (d) Photoluminescence spectrum of a Si photonic crystal cavity and its decay at the cavity resonance. The sample temperature is $4 \mathrm{~K}$.

密度の関数である。 また光共振器中では共鳴波長におい て真空中よりも光の状態密度や局所電場が大きくなる。 このため, ある $Q$ 值とモード体積 $V$ もつ光共振器に共 鳴波長と同一の発光波長をもつ発光体を置いた場合, 発 光体の自然放出レートは真空中に置かれた場合に比べて 増大する. この効果をパーセル (Purcell) 効果という ${ }^{11)}$. 発光の均一線幅が共振器の共鳴線幅よりも小さく, 共鳴 状態にある時, その増大比の最大值はパーセル係数 $F_{p}$ と 呼ばれ，以下の式で表される。

$$
F_{p}=\frac{3 \lambda_{c}^{3} Q}{4 \pi^{2} n^{3} V}
$$

ここで $\lambda_{c}$ は共振器共鳴波長, $n$ は共振器構造の屈折率で ある。一方で共振器と発光体が非共鳴状態の時は, 光に 対する状態密度が小さくなるため自然放出は抑制され る. この式(1)から， $Q$ 值が高くモード体積の小さい光 共振器が大きな自然放出レート増強を得るのに適してい る。そのため, 100 万を超える高い $Q$ 值と $0.1 \mu \mathrm{m}^{3}$ 以下の 極めて小さいモード体積が得られるフォトニック結晶 (Photonic crystal: PhC) 共振器 ${ }^{12}$ に, 狭い発光線幅をもつ 発光体が配置された場合, 大きな自然放出レート増強が 期待できる. Fig. 1 (a) にPhC共振器構造の一例を示す.

なお次節に示すような発光の均一幅が共振器の共鳴線 幅よりも大きい場合は, 式 (1)の共振器 $Q$ 值は発光線幅 による $Q$ 值に置き換えられ， $F_{p}$ は共振器のモード体積に のみ依存する ${ }^{13)}$ 。そのため広帯域の発光に対しては, 共 振器 $Q$ 值は低いが $\mathrm{PhC}$ 共振器よりも更に小さいモード体 積を持つプラズモン共振器がより適していると考えられ る.

これまで光ナノ共振器によるパーセル効果の研究はIII $-\mathrm{V}$ 族半導体で数多く報告されているが, $\mathrm{Si}$ では少な
い. 2007年に室温において光励起されたSiマイクロディ スク共振器による $\mathrm{Si}$ の発光増強が波長 $1100 \mathrm{~nm}$ 帯で報告 され ${ }^{14)}$ ，その後2008年までにモード体積がより小さい $\mathrm{Si}$ $\mathrm{PhC}$ 共振器による $\mathrm{Si}$ バンド端発光の増強が相次いで報告 された ${ }^{15,16)}$ 。その後 $\mathrm{Si} \mathrm{PhC}$ 共振器を用いて通信波長帯に 発光を示す $\mathrm{Si}$ 中の欠陷準位 ${ }^{17,18)}$ や低温下の自由励起子 ${ }^{19)}$ の発光増強が報告されている。最近ではカソードルミ ネッセンスによるSiナノディスク共振器のモード分布測 定 $^{20)}$ や, 銀ナノロッドのプラズモン共振器によって増強 された $\mathrm{Si}$ のホットルミネッセンス ${ }^{21)}$ も報告されているこ とから, 光ナノ共振器による $\mathrm{Si}$ の発光増強の研究が継続 して進められていることがわかる.

\section{3. フォトニック結晶共振器による発光増強}

これまで光ナノ共振器によるSi発光増強の研究はいく つか行われてきたが, その効果は主に発光強度の測定結 果のみを用いて評価されてきた。発光強度増強は共振器 による自然放出レート増加による内部量子効率の変化の みならず，検出系への光取り出し効率の変化にも依存す る。そのため, パーセル効果の評価のためには両者の切 り分けが必要である。更にSiでは自然放出レートが小さ い一方で非発光レートが大きく，時間分解PL測定に よって得られるPLレートは非発光レートに支配されて しまう。このため共振器による自然放出レートの増加を 直にPLレートから評価することは困難である。

しかし，時間分解PL測定は非発光レートの実測值や 共振器作製プロセスに由来する非発光過程を調べる上で 重要である。そこで本研究では低ノイズで高感度の超伝 導単一光子検出器 (Superconducting Single Photon Detector: SSPD）を用いた時間分解PL分光測定装置を新たに構築 
し, 低温のSi PhC共振器内に励起される電子 - 正孔液滴 (Electron-Hole Droplet: EHD)の発光増強をPLレートと共 に調べた。このSSPDによって, 従来困難であった微弱 な $\mathrm{Si}$ 発光の時間分解測定が高い $\mathrm{SN}$ 比 (光電子増倍管の約 100 倍) と時間分解能 (50 ps以下) で可能となった。 EHD は自由励起子と比べて拡散速度が低く, 微小な共振器内 に長い時間留まることから効率的な共振器との相互作用 が期待できる. Fig. 1 (a) は作製したSi PhC共振器の走査 電子顕微鏡 (Scanning Electron Microscope: SEM) 像であ る. 厚さ $160 \mathrm{~nm}$ の Si薄膜に電子線リソグラフィとドライ エッチングによって周期 $299 \mathrm{~nm}$, 直径 $150 \mathrm{~nm}$ の空気孔 アレイを作製した．Si薄膜の下層にあった $\mathrm{SiO}_{2}$ はウェッ トエッチングで除去した。 その後, Si表面における非発 光再結合を抑制するために試料を熱酸化した。

Fig. 1 (b) は今回測定した最低次共鳴モードの光電場強 度分布を示している. 3つの空気孔がない領域で Fig. 1 (b)のように光が閉じ达められ共振器が形成され る. Fig. 1 (c) が測定に用いた光学系である. 試料は連 続波とパルス発振が可能な波長375 nmの半導体レー ザーによって励起し, EHDを Si PhC共振器薄膜中に生成 した。この波長では, 約 $90 \%$ の励起光強度が $\mathrm{Si}$ 薄膜に吸 収されると見積もられるため, 効率よく $\mathrm{Si}$ 薄膜が励起で きる，試料は液体へリウムにより $4 \mathrm{~K} に$ 冷却した，発光 スペクトルの測定には近赤外分光器を用い, 特定の波長 における時間分解PL測定にはSSPDを用いた。

Fig. 1 (d) はSi PhC共振器のPLスペクトルと共鳴波長 におけるPLの時間発展である。図中に見られる波長 $1160 \mathrm{~nm}$ 中心として $1140 \sim 1180 \mathrm{~nm}$ に広がる発光は, EHDからのTO/LOフォノン放出を伴う発光である。一方 で1162 nmに見られる鋭いピークをもつスペクトルが $\mathrm{PhC}$ 共振器の最低次共鳴モードに由来するもので, その 線幅から共振器の $Q$ 值は約 13,000 と見積もられた。この 結果より $\mathrm{Si} \mathrm{PhC}$ 共振器によってEHDの発光強度が大きく 増大していることがわかる. 観測された発光増大分の積 分強度は非共鳴時のそれと比べて約7倍であった。また Fig. 1 (d)に示した時間分解PLから, 共鳴時のPL寿命は $21 \mathrm{~ns}$ と求められた。このPL寿命は非共鳴時 $(1160 \mathrm{~nm})$ で も同じであった。このことから, 実測したPL寿命は共 鳴の有無によって変化が予想されるEHDの自然放出寿 命ではなく, 共鳴に依存しない非発光再結合の寿命を示 していると考えられる.

このPL寿命だけではPhC共振器による自然放出レート の変化を議論できないが, PL強度の結果と合わせて パーセル効果を見積もることができる. $\mathrm{PhC}$ 共振器の大 きさは顕微光学系によって励起・検出される領域 (直径 約 $2 \mu \mathrm{m})$ よりも小さく, EHDの共振器内外の体積比つま り共振器の励起効率は0.05であった。 そのためFig. 2 (d) で観測された発光増強は励起効率によって修正され，共 鳴時のEHD発光積分強度は非共鳴時に比べ約140倍と見 積もられた。この強度比は先に述べたとおり, 内部量子 効率と光取り出し効率の増大によると考えられる. しか し有限領域時間差分法に基づく数值計算によると $\mathrm{PhC}$ 構 造では共鳴, 非共鳴時ともに $\mathrm{PhC}$ 薄膜面内方向に対する
光閉じ込め効果が働くため ${ }^{22)}$, 光取り出し効率は共に 10\%程度でほぼ変化がない. そのため共鳴, 非共鳴時に おける発光強度比はEHD発光の内部量子効率の比とほ ぼ等しいとみなせる。更にPL寿命測定から両条件にお ける非発光レートに変化はないことがわかったため, 内 部量子効率の比は自然放出レートの比に等しいと言え る。つまり観測された $\mathrm{PhC}$ 共振器による発光強度増強 は, 非共鳴時に比べ共鳴時の自然発光レートが約140倍 増加したことに起因すると考えられる。非共鳴時はPhC 構造によるフォトニックバンドギャップによって電磁場 の状態密度は低くなり自然放出レートは抑制される

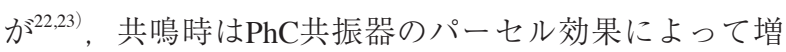
大することから，EHDのような広いスペクトルをもつ 発光体では発光のエネルギーを共振器共鳴に集中させる ことができる。

一方で我々はEHDよりも発光線幅が小さく, 式(1)に 従い高 $Q$ 值共振器によって大きなパーセル効果が期待で きるSi中の発光不純物にも注目している．Si中の多くの 不純物はバンドギャップ内に不純物準位を作ると共に光 励起時に励起子を束縛する。これを束縛励起子という が，不純物を中心としてボーア半径程度の領域に束縛さ れていることから広い運動量スペクトルを有し, フォノ ンを介した運動量補償なしに発光遷移が可能である。こ のような発光遷移は, 不純物ドープ $\mathrm{Si}$ のPL測定におい て, 鋭いゼロフォノンライン(Zero Phonon Line: ZPL) と して観測される ${ }^{24)}$.

一例として我々がイオン注入と高速アニールを用いて $\mathrm{Si}$ 薄膜にリンと銅をドープし，PLスペクトルを測定した 結果をFig. 2に示す.リンドープSiでは波長1079 nmにリ ンドナー束縛励起子ZPLに由来する発光ピークが観測さ れ，ドープ濃度を高くするとその発光強度は増加し
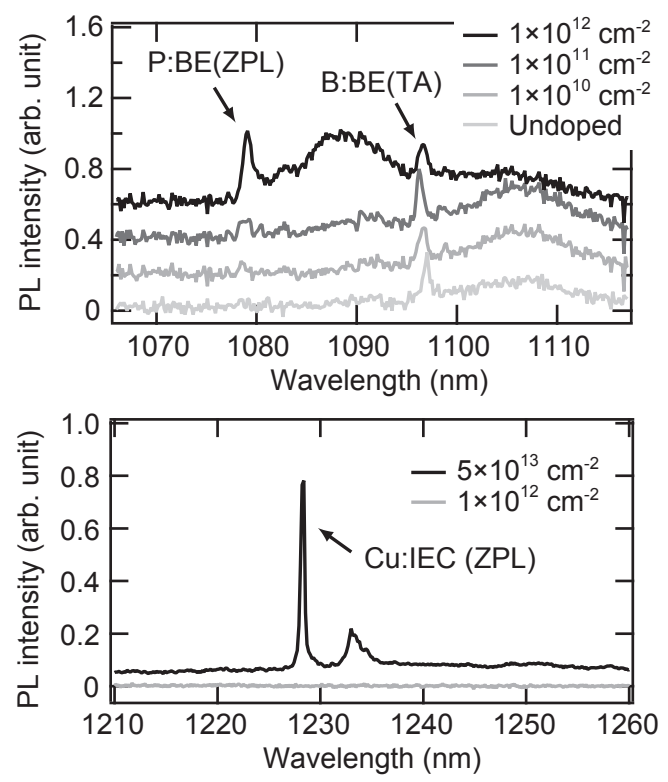

Fig. 2 Photoluminescence spectra for impurity-doped Si thin films with different impurity doses. The upper (lower) figure shows the spectrum for a phosphorus (copper)-doped Si film. The sample temperature is $4 \mathrm{~K}$. 
た ${ }^{25)}$ 。また銅ドープ Siでは波長1228 nmに鋭く強い発光 ピークが観測された。これは，銅による深い不純物準位 によって束縛された励起子(これを銅等電子中心という) のZPL発光である ${ }^{26,27)}$. 両者とも50 K以下の低温でのみ 観測されるが，Si中のリンは，極めて長い電子や核のス ピン寿命を持つことから, 量子メモリビットとして注目 されている ${ }^{28,29)}$ 、また銅等電子中心はオージェ過程によ る非発光がないと考えられており, 浅い不純物の束縛励 起子よりも強い発光を示す。そのため近年では等電子中 心を量子ビットとして用いた量子光デバイスも提案され ている30).

\section{4. 自然ラマン散乱光の増強}

これまでPhC共振器によるSiの自然放出光増強につい て述べてきたが, 共振器によって増強されるのは自然放 出光だけではない.同様の原理で自然ラマン散乱光につ いても共振器による増強が期待できる ${ }^{31}$. そここで我々は 低次元に閉じ込められた電子とフォノンによってユニー クな物性を示すカーボンナノチューブ (Carbon nanotube: CNT)に注目し, Si PhC共振器によってCNTの自然ラマ ン散乱光を増強することに成功した ${ }^{32)}$. 本節ではその結 果を紹介させて頂く.

Fig. 3 (a)に作製した試料のSEM写真を示す.この写 真に示すように, 点欠陷型 $\mathrm{Si} \mathrm{PhC}$ 共振器の上に半導体性 CNTを分散させた。共振器部分にあるCNTは約 1,000 本 程度と見積もられる。この試料を波長 $940 \mathrm{~nm}$, 線幅約 $10 \mathrm{pm}$ の連続発振チタンサファイアレーザーによって室 温で励起した時のラマンスペクトルをFig. 3 (b) に示 す. 測定光学系はFig. 1 (c) とほぼ同等である. $1600 \mathrm{~cm}^{-1}$ 付近にCNTの光学フォノンに起因してストークスラマン
ピーク (Gライン)が見られる。本研究では対称性により 分裂した $G$ ラインのうち最も強い $G^{+}$ラインに注目し, 励 起波長を掃引することで $G^{+}$ラインの波長を $\mathrm{PhC}$ 共振器の 共鳴波長に合わせた. Fig. 3 (c) にそのときのラマンス ペクトルを示す。図では共振器の共鳴波長を示すために 紫外レーザーで励起された $\mathrm{Si} \mathrm{PhC}$ 共振器のPLスペクトル を重ねてある。 $G^{+}$ラインが共鳴波長 $1117 \mathrm{~nm}$ と一致する とき，ラマン強度が増大することが観測された。このと きの $G^{+}$ラインピーク強度の波長依存性を平坦な $\mathrm{Si}$ 薄膜上 にあるCNTのピーク強度と共にFig. 3 (d) に示す. ラマ ンピーク強度は確かに共振器の共鳴波長で増強されてい ることがわかった，共振器共鳴によるラマン強度増加分 は非共鳴時の強度とほぼ同等で，平坦な Si上CNTの強度 に比べると約5倍大きい．前節のEHDの発光増強と同様 にPhC共振器上CNTの励起効率を考慮すると, 平坦な $\mathrm{Si}$ 上にあるCNTのラマンに比べ共振器と結合したCNTでは ラマン強度が約100倍増強されていることがわかった。 また数值計算の結果と合わせると, このラマン強度増強 は，共振器よってラマン光の取り出し効率が平坦なSiに 比べて約20倍改善したこと，および光の状態密度が5倍 増大したことが原因であると考えられる。

\section{5. まとめ}

本稿では, Si PhC共振器を用いたSiやCNTの放射遷移 増強について我々の研究結果を中心に紹介した。最近で は, 高 $Q$ 值の銅ドープSi PhC共振器によってFig. 2で紹介 した銅等電子中心の自然放出レートが増大することを時 間分解PLによって直接観測し, $\mathrm{Si}$ 不純物のパーセル効果 を実証することに成功している。今後 $\mathrm{PhC}$ 共振器のみな らずプラズモン共振器などの光ナノ共振器を用いた高輝 (a)

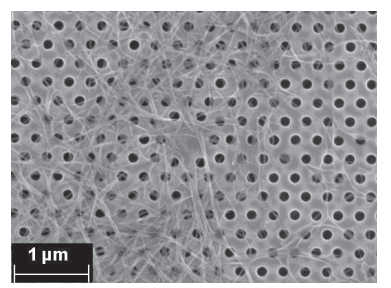

(b)

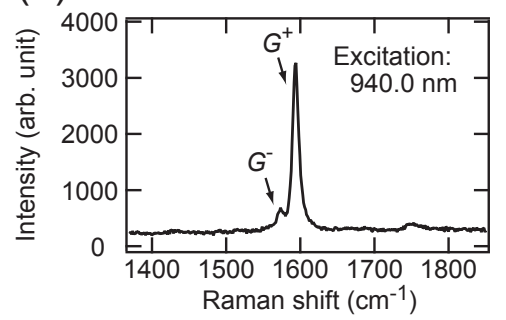

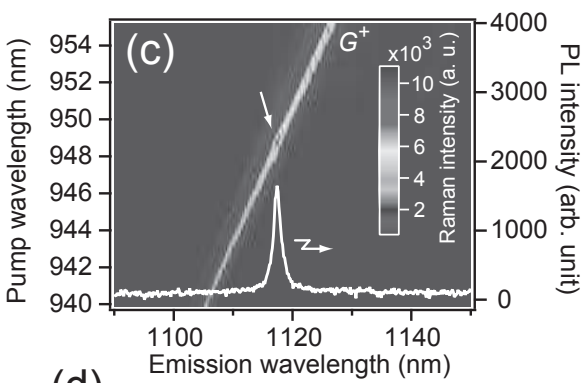

(d)

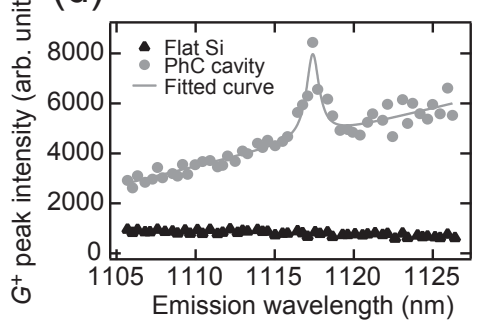

Fig. 3 (a) SEM picture of a CNT-deposited Si photonic crystal cavity. (b) Raman spectrum of the sample excited by laser light with a wavelength of $940.0 \mathrm{~nm}$. (c) Raman spectra as a function of the excitation laser wavelength. The photoluminescence spectrum of a Si photonic crystal cavity is also shown for indicating the cavity resonance. (d) Peak intensities of the $G^{+}$Stokes Raman line of carbon nanotubes deposited on a photonic crystal cavity and a flat Si film. The solid line shows the fitted curve with a Lorentz peak. 
度 $\mathrm{Si}$ 発光デバイスや $\mathrm{Si}$ 不純物を用いた量子光デバイスの 研究が更に進展することを期待している.

また後半ではSi PhC共振器がCNTの自然ラマン散乱も 増強可能であることを紹介した。この分野では最近 $\mathrm{Si}$ $\mathrm{PhC}$ 共振器によるSiラマンレーザーが報告されてい る33). CNTは大きなラマンゲインを有していると考えら れており，かつ高いフォノンエネルギーによって大きな ラマンシフト示す。このためSi PhC共振器によってCNT の誘導ラマン散乱やラマンレージングが今後観測されれ ば，より低しきい值で動作する小型ラマン光源や波長変 換デバイスが実現され， $\mathrm{Si}$ とカーボン材料を用いたIV族 ハイブリットデバイスとして応用展開できると考えている。

\section{謝 辞}

NTTの倉持 栄一氏には試料作製で，谷山 秀昭氏には 数值計算でご協力頂きました。 また西口克彦氏，Abdul Shakoor氏にご助力頂きました。 ここに感謝申し上げま す.

\section{参考文献}

1) M. A. Green, J. Zhao, A. Wang, P. J. Reece, and M. Gal: Nature 412 (2001) 805

2) S. G. Cloutier, P. A. Kossyrev, and J. Xu: Nature Mater. 4 (2005) 887.

3) T. D. Ladd, J. R. Goldman, F. Yamaguchi, Y. Yamamoto, E. Abe, and K. M. Itoh: Phys. Rev. Lett. 89 (2002) 017901

4) P. van Loock, T. D. Ladd, K. Sanaka, F. Yamaguchi, K. Nemoto, W. J. Munro, and Y. Yamamoto: Phys. Rev. Lett. 96 (2006) 240501.

5) L. I. Schiff: Quantum Mechanics 3rd ed. (McGraw-Hill, New York, 1968) Chap. 11

6) M. V. Fischetti and S. E. Laux: J. Appl. Phys. 80 (1996) 2234.

7) J. R. Jain, A. Hryciw, T. M. Baer, D. A. B. Miller, M. L. Brongersma, and R. T. Howe: Nature Photon. 6 (2012) 398.

8) L. Pavesi, L. Dal Negro, C. Mazzoleni, G. Franzo, and F. Priolo: Nature 408 (2000) 440.

9) S. Godefroo, M. Hayne, M. Jivanescu, A. Stesmans, M. Zacharias, O. I. Lebedev, G. Van Tendeloo, and V. V. Moshchalkov: Nat. Nanotechnol. 3 (2008) 174.

10) S. Saito, D. Hisamoto, H. Shimizu, H. Hamamura, R. Tsuchiya, Y. Matsui, T. Mine, T. Arai, N. Sugii, K. Torii, et al.: Jpn. J. Appl.
Phys. 45 (2006) L679.

11) E. M. Purcell: Phys. Rev. 69 (1946) 681.

12) T. Tanabe, M. Notomi, E. Kuramochi, A. Shinya, and H. Taniyama: Nature Photon. 1 (2006) 49.

13) H. Y. Ryu and M. Notomi: Opt. Lett. 28 (2003) 2390.

14) J. S. Xia, Y. Ikegami, K. Nemoto, and Y. Shiraki: Appl. Phys. Lett. 90 (2007) 141102.

15) S. Iwamoto, Y. Arakawa, and A. Gomyo: Appl. Phys. Lett. 91 (2007) 211104.

16) M. Fujita, Y. Tanaka, and S. Noda: IEEE J. Sel. Top. Quantum Electron. 14 (2008) 1090.

17) R. Lo Savio, S. L. Portalupi, D. Gerace, A. Shakoor, T. F. Krauss, L. O’Folain, L.C. Andreani, and M. Galli: Appl. Phys. Lett. 98 (2011) 201106.

18) A. Shakoor, R. Lo Savio, P. Cardile, S. L. Portalupi, D. Gerace, K. Welna, S. Boninelli, G. Franzo, F. Priolo, T. F. Krauss, et al.: Laser Photon. Rev. 7 (2013) 114.

19) N. Hauke, T. Zabel, K. Müller, M. Kaniber, A. Laucht, D. Bougeard, G. Abstreiter, J. J. Finley, and Y. Arakawa: New J. Phys. 12 (2010) 053005.

20) T. Coenen, J. van de Groep, and A. Polman: ACS Nano 7 (2013) 1689.

21) C-H Cho, C. O. Aspetti, J. Park, and R. Agarwal: Nature Photon. 7 (2013) 285.

22) M. Fujita, S. Takahashi, Y. Tanaka, T. Asano, and S. Noda: Science 308 (2005) 1296.

23) Q. Wang, S. Stobble, and P. Lodahl: Phys. Rev. Lett. 107 (2011) 167404.

24) P. J. Dean, J. R. Haynes, and W. F. Flood: Phys. Rev. 161 (1967) 711.

25) H. Sumikura, K. Nishiguchi, Y. Ono, A. Fujiwara, and M. Notomi: Opt. Express 19 (2011) 25255.

26) S. P. Watkins, U. O. Ziemelis, M. L. W. Thewalt, and R. R. Parsons: Solid State Commun. 43 (1982) 687.

27) J. Weber, H. Bauch, and R. Sauer: Phys. Rev. B 25 (1982) 7688.

28) J. J. Morton, A. M. Tyryshkin, R. M. Brown, S. Shankar, B. W. Lovett, A. Ardavan, T. Schenkel, E. E. Haller, J. W. Ager, and S. A. Lyon: Nature 455 (2008) 1085.

29) M. Steger, K. Saeedi, M. L. W. Thewalt, J. J. Morton, H. Riemann, N. V. Abrosimov, P. Becker, and H. -J. Pohl: Science 336 (2012) 1280

30) T. Ishikawa, K. Koga, T. Itahashi, L. S. Vlasenko, and K. M. Itoh: Physica B 404 (2009) 4552.

31) A. Fainstein, B. Jusserand, and V. Thierry-Mieg: Phys. Rev. Lett. 75 (1995) 3764.

32) H. Sumikura, E. Kuramochi, H. Taniyama, and M. Notomi: Appl. Phys. Lett. 102 (2013) 231110.

33) Y. Takahashi, Y. Inui, M. Chihara, T. Asano, R. Terawaki, and S. Noda: Nature 498 (2013) 470.
フォトニック結晶共振器 (photonic crystal cavity)

フォトニック結晶中に形成される電磁波を閉じ込める ことができる構造. 屈折率が周期的に変化する構造体 (フォトニック結晶)に構造欠陥を導入して形成される。 従来のミラー対共振器などに比べて小さく, 例えば半導 体で作製された共振器の大きさは閉じ込め電磁波の波長
以下である。また高精度のナノ加工技術と数値計算を用 いた構造設計の最適化により， $Q$ 值 100 万上の共振器 が得られている。集積化が比較的容易であることからナ ノ発光デバイスやその他の微小光学素子への応用が進め られている。

(角倉 久史)

\section{パーセル効果 (purcell effect)}

共振器を用いて励起状態にある物質の自然放出レート を増大させる効果. 自然放出レートは物質が放射する電 磁波の状態密度に依存するため，共鳴共振器による大き な状態密度によって自然放出レートが増大する。1946年 に米国のE. M. Purcellによって, ラジオ波帯共振器を用 いた核スピン緩和時間の短縮を目的として理論的に示さ
れた。現在までにミラー対や誘電体微小共振器などの多 様な共振器を用いて，アルカリ金属原子や半導体などで パーセル効果が観測されている。この効果は物質の発光 制御が可能なため，レーザーに代表される発光デバイス の高輝度，高効率化に応用されている。（角倉 久史） 